\title{
What Can We Learn from a Race with One Runner? \\ A Comment on Foreman-Peck and Zhou, 'Late Marriage as a Contributor to the Industrial Revolution in England”•
}

The European Marriage Pattern, characterised by late marriage for women, high proportions never marrying, and predominantly nuclear families, has been put forward as a major cause of European economic growth by a number of authors. ${ }^{1}$ However, as Dennison and Ogilvie pointed out in their analysis of 4,705 observations for 39 European societies, the evidence does not support this idea: in fact, the most extreme versions of the European Marriage Pattern were found in slow-growing economies such as those in Central and Nordic Europe. ${ }^{2}$ Nevertheless, Foreman-Peck and Zhou (henceforth FPZ), while accepting that the European Marriage Pattern was not a sufficient condition for economic development, argue that the late age of female first marriage was a major contributor to the Industrial Revolution in England. ${ }^{3}$ The purpose of the present comment is to make two points about that argument: first, contrary to their claim, FPZ do not actually test their hypothesis; second, evidence from other European economies makes it extremely implausible.

FPZ write that 'It is unlikely that any single institution or event was responsible for a transformation of society - such as the English industrial revolution ... Rather, there must have been an interaction of a considerable number of elements'. ${ }^{4}$ We share this view, and in principle we are sympathetic to the approach that FPZ claim to use, which they describe as follows:

The approach here is therefore to embed the idea to be tested in a model, a simplification of reality, that conforms with the salient evidence. The central hypothesis is that the late age of female first marriage was a major contributor to England's industrial revolution because of the contribution to human capital accumulation ... [broadly defined as] advances in useful knowledge, from schooling, from successful technological innovations, from parenting, and from many other sources. ${ }^{5}$

In practice, however, FPZ do not use this approach. A test of the importance of late female age at first marriage (henceforth FAFM) requires its contribution to be compared with that of other possible influences on the Industrial Revolution. Such an analysis will certainly need to

\footnotetext{
- We thank three anonymous referees for their helpful comments.

${ }^{1}$ Voigtländer and Voth, 'Why'; eisdem, 'How'; Greif, 'Family'; De Moor and Van Zanden, 'Girlpower'; Greif and Tabellini, 'Cultural'.

${ }^{2}$ Dennison and Ogilvie, 'Does'.

${ }^{3} \mathrm{FPZ}$, 'Late'.

${ }^{4} \mathrm{FPZ}$, 'Late', p. 2.

${ }^{5}$ FPZ, 'Late', p. 2.
} 
make simplifications in order to focus clearly on the different influences whose contributions have to be evaluated. But the simplifications cannot be so far-reaching that no other possible influences on the English Industrial Revolution are analysed in the model. Yet this is what FPZ do: their model, by construction, excludes any contribution from these other influences. The only non-stochastic influence on the growth of output and real wages in the FPZ model is female marriage age. Apart from shocks, there is no other mechanism by which output and real wages can rise. The FPZ model is therefore incapable of evaluating the importance of late FAFM relative to any other influence, so it cannot provide a test of whether late FAFM was a major contributor to English industrialisation.

In the FPZ model, the economy's production technology, as represented by an aggregate production function, is assumed to be constant over their sample period, the 570 years from c. 1300 to c. $1870{ }^{6}$ The growth in output over this period is modelled as resulting from two things: growth in labour supply, reflecting population growth; and growth in human capital, broadly defined to include, inter alia, technological innovations. The growth in human capital is assumed to result from parents' choice of child quality, which FPZ envisage as reflecting the informal education provided to children by mothers. ${ }^{7}$ In the FPZ model, as FAFM rises, the price of child quality falls. This is the crucial mechanism that links female marriage age and economic growth: later FAFM leads to more human capital accumulation. The FPZ justification for this key relationship is that later marriage meant that young women spent more time as servants and in so doing added new skills to those they had absorbed from their parents. ${ }^{8}$ The greater skills that later marriage gave women then enabled them to be better providers of informal education to their own children and hence resulted in more rapid accumulation of broadly-defined human capital. ${ }^{9}$ In the FPZ model, therefore, technological innovations, a component of their broad definition of human capital, are due to late FAFM.

The FPZ model allows both mortality and productivity shocks to influence the growth rate of output and real wages, but the only non-stochastic mechanism in the model is that later FAFM increases broad human capital accumulation. When this model is applied to the data for the English economy from c. 1300 to c.1870, it is no surprise that later female marriage age appears to play a critical role in economic growth. Over this period, there was a substantial rise in per capita output. Given the FPZ assumption of an unchanging production function, the only way in which the innovations that are widely agreed to have been a key

\footnotetext{
${ }^{6} \mathrm{FPZ}$, 'Late', p. 15.

${ }^{7}$ FPZ, 'Late', p. 10.

${ }^{8} \mathrm{FPZ}$, 'Late', pp. $9-10$.

${ }^{9}$ FPZ, 'Late', p. 10.
} 
determinant of the rise in output can be reflected in the FPZ model is through human capital, which they define to include successful technological innovations. The accumulation of human capital therefore has to provide a great deal of the proximate explanation of the rise in per capita output. Since the key determinant of human capital accumulation in the FPZ model is late FAFM, it is inevitable that late female marriage age appears to be a major contributor to the Industrial Revolution. But this conclusion is not the result of evaluating the impact of several different influences and establishing that late FAFM was one of the most important. Rather, it is because the FPZ model is so simplified that there is no other way in which the observed rise in English output can be made consistent with the model. It is analogous to announcing that a certain person is the fastest runner in the world on the basis of a race in which that person was the only competitor.

It is therefore incorrect for FPZ to claim that, once their model has been fitted to English data, it can be used to demonstrate the importance of late FAFM for the Industrial Revolution. The procedure by which they purport to do this is to remove the effect of FAFM on the price of child quality in their model and simulate what happens to economic growth, as measured by increases in real wages. ${ }^{10}$ When they do this, their model predicts hardly any economic growth between 1300 and $1870 .{ }^{11}$ The problem with this procedure is that when the model is fitted to the English data it is, as we have seen, compelled to assign an important influence to late FAFM. Once the effect of FAFM on the price of child quality is removed, there is nothing else in the model that will allow it to be consistent with the observed rise in per capita output. Thus the only thing the simulation tells us is that, when the sole mechanism which enables the FPZ model to fit the data well is eliminated, the model will fit the data much less well. It does not tell us anything about the importance of late FAFM for the English Industrial Revolution. The importance of late FAFM for the Industrial Revolution is assumed by FPZ in the way that they construct their model. It does not have to be demonstrated by simulation.

In their conclusion, FPZ acknowledge that other European economies had marriage patterns similar to the English one but did not experience a similar pattern of economic growth. ${ }^{12}$ They suggest that this might be because the human capital accumulation induced by the marriage pattern began later in other countries, but they do not present any evidence that this was the case. Their failure to discuss the difference between England and these other

\footnotetext{
${ }^{10} \mathrm{FPZ}$, 'Late', pp. 2, 3, 21.

${ }_{11}^{11}$ FPZ, 'Late', p. 18, Figure 5.

${ }^{12}$ FPZ, 'Late', p. 24.
} 
European economies might not matter if they had, in fact, shown that late FAFM was a major contributor to the English industrial revolution. But, as we have seen, FPZ do not show this. In order to assess whether late FAFM and high female servanthood played an important role in English industrialisation, as FPZ claim, it is therefore essential to consider the experience of other European economies that also had these characteristics.

We know from Dennison and Ogilvie that many slow-growing European economies had higher FAFM than did England. In addition, while life-cycle servanthood was certainly prevalent among young women in England and Wales, it was also important in Denmark, ${ }^{13}$ Iceland, ${ }^{14}$ Norway, ${ }^{15}$ and Sweden, ${ }^{16}$ none of which experienced rapid economic growth or early industrialisation. Servanthood, especially for females, was also widespread in Flanders (modern Belgium) ${ }^{17}$ and the Netherlands. ${ }^{18}$ Female servants were particularly numerous in urban centres because of the high productivity of female workers in secondary- and tertiarysector occupations, but they were also widespread in rural regions afflicted by high male outmigration because of stagnant economic opportunities. High rates of female life-cycle service were thus associated both with economic growth and with economic stagnation in pre-modern Europe.

Did England accumulate more human capital than these other European economies with late FAFM and widespread female servanthood? Answering this question is difficult, because FPZ's concept of human capital is a broad one which they admit to be hard to measure, covering as it does a wider range of skills than literacy, numeracy, and schooling. ${ }^{19}$ However, as far as the narrower components of human capital are concerned, the answer is no: Dennison and Ogilvie show that many slow-growing European economies had more of them than England. ${ }^{20}$

It might still be argued that high FAFM and female servanthood ensured that women invested in their own human capital informally in the labour market, even if their level of formal education varied greatly. But a further serious weakness in the FPZ model emerges

\footnotetext{
${ }^{13}$ Elklit, 'Household', p. 118; Moring, 'Nordic', p. 82.

${ }^{14}$ Gunnlaugsson, 'Living', p. 104; Garðarsdóttir, 'Residence', p. 9.

${ }^{15}$ Moring, 'Nordic', pp. 82-3.

${ }^{16}$ Gaunt, 'Pre-industrial', p. 200; Lundh, 'Households', pp. 40, 52; idem, 'Social', p. 62; Moring, 'Nordic', p. 82.

${ }^{17}$ Wall, 'Composition', p. 448; Leboutte, 'Saving', p. 148; Lambrecht, 'Unmarried', p. 3.

${ }^{18}$ Van de Woude, 'Variations', pp. 306-8, 314; Bras, 'Maids', p. 221; idem, 'Social', p. 248; Kok and Mandemakers, 'Life-course', p. 289; Van Nederveen Meerkerk and Paping, 'Beyond', p. 460; A. Bouman and T. De Moor, 'The commercial household: servants and lodgers as alternatives to intergenerational support in town and countryside (the Netherlands, 17th Century)', paper presented at the Economic and Social History seminar (University of Utrecht, 21 March 2013), p. 18.

${ }^{19}$ FPZ, 'Late', p. 9.

${ }^{20}$ Dennison and Ogilvie, 'Does', pp. 678-9.
} 
when it is confronted with the evidence on women's economic opportunities in different European societies. Whether being a servant (or being in the labour force at all) enabled women to invest in their skills depended partly on what kind of work they were allowed to do. ${ }^{21}$ Where guilds of craftsmen, proto-industrialists, tradesmen, and other service occupations barred maidservants and other unmarried females unrelated to guild masters from engaging in skilled work, such human capital investment was inevitably lower. In England, guilds were weaker and less able to exclude females, so the informal human capital investment women could obtain through learning by doing in skilled occupations was probably higher. This was caused not by the pattern of late marriage and widespread servanthood for females (which existed in both England and other parts of northwest, central, and nordic Europe, and was more intense in many of these other societies) but by the comparative weakness of guild restrictions on women's work in England. ${ }^{22}$ Likewise, where manorial and communal restrictions limited the kinds of work women were allowed to do, as in many parts of central Europe, women were either excluded from the labour force altogether or restricted to menial, unskilled activities which provided them with less opportunity or incentive to invest in their own human capital through learning by doing. ${ }^{23}$ It was these factors that led early modern foreign travellers to remark on the astonishing economic autonomy of English women, as in 1592 when the heir to the Duchy of Württemberg remarked that

the women [in England] have much more liberty than perhaps in any other place; they also know well how to make use of it, for they go out dressed in exceedingly fine clothes ... [England is] a paradise for women, a prison for servants, and a hell or purgatory for horses ... for the females have great liberty and are almost like masters, whilst the poor horses are worked very hard. ${ }^{24}$

Neglect of the wider institutional framework also vitiates the FPZ treatment of technological innovation as the source of economic growth and industrialisation. FPZ treat innovation as one of the components of their broad concept of human capital, which they view as arising from late FAFM. Thus the only possible influence on innovation in their model is FAFM. This is inconsistent with everything that is known about the history of technological innovation in a long and rich literature on the subject. Lively debate still rages

\footnotetext{
${ }^{21}$ Dennison and Ogilvie, 'Does', pp. 672-6; eisdem, 'Institutions', pp. 207-8.

${ }^{22}$ Snell, Annals, p. 306 with n. 81; Laurence, 'How', pp. 129, 133-4; Prior, 'Freedom', pp. 138-40; Wiesner, 'Guilds'; Ogilvie, Bitter, pp. 328-34.

${ }^{23}$ Ulbrich, Shulamit, pp. 35, 138, 306; Rippmann, 'Frauenarbeit', p. 35; Ryter, 'Geschlechtsvormundschaft', p. 506; Ogilvie and Edwards, 'Women'; Ogilvie, Bitter, pp. 333-4, 338, 344-6.

${ }^{24}$ Quoted in Rye, England, pp. 7, 17.
} 
about why England should have experienced the first industrial revolution, with some scholars emphasizing high wages and cheap coal, ${ }^{25}$ others the industrial application of Enlightenment science, ${ }^{26}$ and still others the emergence of bourgeois values. ${ }^{27}$ A further important influence was the wider institutional framework. The gradual weakening in England of traditional institutional constraints imposed by powerful manorial landlords, strong village communities, privileged towns, and occupational corporations slowly improved the operation of factor and product markets over a period of centuries. People who devised technological innovations could obtain the necessary inputs in the required quantities at the lowest possible cost, without opposition from entrenched interest-groups. And they could rely on being able to sell the output at a price and in a quantity that would gain them enough for it to be worth their while incurring the costs and risks of experimenting. This may help to explain why path-breaking 'macro-inventions' were devised in many places in Europe, but the 'micro-inventions' that made them work in practice were concentrated in just a few. As the Basel calico-printer, Jean Ryhiner, remarked in 1766, 'the English cannot boast of many inventions, but only of having perfected the inventions of others; whence comes the proverb that for a thing to be perfect it must be invented in France and worked out in England' ${ }^{28}$

None of these wider influences on innovation was brought into being by late female marriage and widespread female servanthood. The evidence suggests that whether a society experienced economic growth depended not on its marriage pattern, but on its wider institutional framework. In early modern England, late marriage and high servanthood for women existed within a framework in which there were few barriers to entry so that factor and product markets functioned well; economic growth was typically positive and eventually dramatic. In the early modern Netherlands, late marriage and high servanthood for women initially existed in a similar framework of well-functioning markets and impressive economic growth; but after c. 1700 the economy stagnated and industrialisation was delayed, for reasons that remain unclear. In German-speaking central Europe and the Scandinavian societies, late marriage and high servanthood for females existed in a very different framework of interlinked factor markets, mobility restrictions (including, in some areas, serfdom), and significant entry barriers (for most women and many men) created by corporative, communal, and manorial privileges; until these institutional obstacles were removed, economic growth remained sluggish.

\footnotetext{
${ }^{25}$ Allen, British.

${ }^{26}$ Mokyr, Enlightened.

${ }^{27}$ McCloskey, Bourgeois.

${ }^{28}$ Quoted in Wadsworth and Mann, Cotton, p. 413.
} 
Late age at first marriage may only have been possible in a framework of strong nonfamilial institutions that could substitute for families in providing labour, insurance, welfare, and old age care to unmarried individuals and fragile nuclear families. ${ }^{29}$ But non-familial institutions were highly variegated. Some of them, such as well-functioning markets and impartial public institutions, benefited human capital investment and innovation. Others did not. Occupational guilds, closed corporative communities, strong manorial institutions, restrictive religious institutions, and absolutist states tended to restrict human capital investment to privileged groups and block innovations that threatened entrenched producers. A final weakness of FPZ, we suggest, is that they wholly neglect the non-familial institutional framework that circumscribed both demographic and economic decision-making before and during European industrialization.

In conclusion, FPZ's claim that late FAFM was a major contributor to the Industrial Revolution in England is fatally flawed by the absence of any comparative dimension in their analysis. They consider neither the other European economies which had late FAFM throughout the early modern period but industrialised a century or more after England, nor any possible influences on English industrialisation other than late FAFM. FPZ appear to believe that, because their claim is only that late FAFM was a major contributor to industrialisation, not that it was a sufficient condition for it, the former lacuna does not matter. But, as we have explained, FPZ fail to show that late FAFM was indeed a major contributor. Consequently it is important to ask a question to which FPZ provide no answer: if late FAFM and widespread servanthood were major contributors to English industrialisation because these features generated the accumulation of broad human capital, why did this only happen in England? The answer suggested by the experience of other European countries is that the premise of this question is wrong: late female marriage and widespread servanthood were not major contributors to English industrialisation.

\footnotetext{
${ }^{29}$ Laslett, 'Family', pp. 154-6, 160, 174; Solar, 'Poor'; Dennison and Ogilvie, 'Does', pp. 686-7; eisdem, 'Institutions', pp. 206-7, 216-17.
} 


\section{Footnote references}

Allen, R. C., The British Industrial Revolution in global perspective (Cambridge, 2009).

Bouman, A. and De Moor, T., 'The commercial household: servants and lodgers as alternatives to intergenerational support in town and countryside (the Netherlands, 17th Century)', paper presented at the Economic and Social History seminar (University of Utrecht, 21 March 2013).

Bras, H., 'Maids to the city: migration patterns of female domestic servants from the province of Zeeland, the Netherlands (1850-1950)', The History of the Family, 8 (2003), pp. 217-46.

Bras, H., 'Social change, the institution of service and youth: the case of service in the lives of rural-born Dutch women, 1840-1940', Continuity and Change, 19 (2004), pp. 241-64.

De Moor, T. and Van Zanden, J. L., 'Girlpower: the European Marriage Pattern and labour markets in the North Sea region in the late medieval and early modern period', Economic History Review, 63 (2010), pp. 1-33.

Dennison, T. and Ogilvie, S., 'Does the European Marriage Pattern explain economic growth?', Journal of Economic History, 74 (2014), pp. 651-93.

Dennison, T. and Ogilvie, S., 'Institutions, demography, and economic growth', Journal of Economic History, 76 (2016), pp. 205-17.

Elklit, J., 'Household structure in Denmark 1769-c.1890', in S. Åkerman, H. C. Johansen and D. Gaunt, eds., Chance and change: social and economic studies in historical demography in the Baltic Area (Odense, 1978), pp. 109-21.

Foreman-Peck, J. and Zhou, P., 'Late marriage as a contributor to the Industrial Revolution in England', Economic History Review (2018 early view), pp. 1-27.

Garðarsdóttir, Ó., 'Residence patterns of the elderly in early eighteenth-century Iceland', The History of the Family, 21 (2016), pp. 5-20.

Gaunt, D., 'Pre-industrial economy and population structure: the elements of variance in early modern Sweden', Scandinavian Journal of History, 2, no. 1-4 (1977), pp. 183-210.

Greif, A., 'Family structure, institutions, and growth: the origins and implications of Western corporations', American Economic Review: Papers and Proceedings, 96:2 (2006), pp. 30812. [pagination restarts with each issue]

Greif, A. and Tabellini, G., 'Cultural and institutional bifurcation: China and Europe compared', American Economic Review: Papers and Proceedings, 100:2 (2010), pp. 135-40. [pagination restarts with each issue]

Gunnlaugsson, G. Á., 'Living arrangements of the elderly in a changing society: the case of Iceland, 1880-1930', Continuity and Change, 8 (1993), pp. 103-25.

Kok, J. and Mandemakers, K., 'A life-course approach to co-residence in the Netherlands, 1850- 
1940', Continuity and Change, 25 (2010), pp. 285-312.

Lambrecht, T. A., 'Unmarried adolescents and filial assistance in eighteenth-century Flanders', MPRA Papers 35400 (2011).

Laslett, P., 'Family, kinship and collectivity as systems of support in preindustrial Europe: a consideration of the "nuclear-hardship" hypothesis', Continuity and Change, 3 (1988), pp. $153-76$.

Laurence, A., 'How free were English women in the seventeenth century?', in E. Kloek, N. Teeuwen and M. Huisman, eds., Women of the Golden Age: an international debate on women in seventeenth-century Holland, England, and Italy (Hilversum, 1994), pp. 127-35.

Leboutte, R., "Saving male time, exploiting female labour: the woman as the "driving force" in premodern society, 1700-1914', The History of the Family, 11 (2006), pp. 145-50.

Lundh, C. 'Households and families in pre-industrial Sweden', Continuity and Change, 10 (1995), pp. 33-68.

Lundh, C., 'The social mobility of servants in rural Sweden, 1740-1894', Continuity and Change, 14 (1999), pp. 57-89.

McCloskey, D. N., Bourgeois dignity: why economics can't explain the modern world (Chicago, 2010).

Mokyr, J., The enlightened economy: an economic history of Britain, 1700-1850 (Princeton, NJ, 2009).

Moring, B., 'Nordic family patterns and the North-West European household system', Continuity and Change, 18 (2003), pp. 77-109.

Ogilvie, S., A bitter living: women, markets, and social capital in early modern Germany (Oxford, 2003).

Ogilvie, S. and Edwards, J., 'Women and the "second serfdom": evidence from early modern Bohemia', Journal of Economic History, 60 (2000), pp. 961-94.

Prior, M., 'Freedom and autonomy in England and the Netherlands: women's lives and experience in the seventeenth century', in E. Kloek, N. Teeuwen and M. Huisman, eds., Women of the Golden Age: an international debate on women in seventeenth-century Holland, England, and Italy (Hilversum, 1994), pp. 137-40.

Rippmann, D., 'Frauenarbeit Im Wandel. Arbeitsteilung, Arbeitsorganisation Und Entlöhnung Im Weinbau Am Oberrhein (15./16. Jahrhundert)', in H. Wunder and C. Vanja, eds., Weiber, Menscher, Frauenzimmer. Frauen in Der Ländlichen Gesellschaft 1500-1800 (Göttingen, 1996), pp. 26-59.

Rye, W. B., England as seen by foreigners in the days of Elizabeth and James I (1865).

Ryter, A., 'Die Geschlechtsvormundschaft in Der Schweiz: Das Beispiel Der Kantone Basel- 
Landschaft Und Basel-Stadt', in U. Gerhard ed., Frauen in Der Geschichte Des Rechts: Von Der Frühen Neuzeit Bis Zur Gegenwart (Munich, 1997), pp. 494-508.

Snell, K. D. M., Annals of the labouring poor: social change and agrarian England 1660-1900 (Cambridge, 1985).

Solar, P. M., 'Poor relief and english economic development before the Industrial Revolution', Economic History Review, XLVIII (1995), pp. 1-22.

Ulbrich, C., Shulamit Und Margarete: Macht, Geschlecht Und Religion in Einer Ländlichen Gesellschaft Des 18. Jahrhunderts (Vienna / Cologne / Weimar, 1999).

Van der Woude, A. M., 'Variations in the size and structure of the household in the United Provinces of the Netherlands in the seventeenth and eighteenth centuries', in P. Laslett and R. Wall, eds., Household and family in past time (Cambridge, 1972), pp. 299-318.

Van Nederveen Meerkerk, E. and Paping, R., 'Beyond the census. Reconstructing Dutch women's labour market participation in agriculture in the Netherlands, c.1830-1910', The History of the Family, 19 (2014), pp. 447-68.

Voigtländer, N. and Voth, H.-J., 'Why England? Demographic factors, structural change and physical capital accumulation during the Industrial Revolution', Journal of Economic Growth, 11 (2006), pp. 319-61.

Voigtländer, N. and Voth, H.-J., 'How the West “invented” fertility restriction', American Economic Review, 103 (2013), pp. 2227-64.

Wadsworth, A. P. and Mann, J. de L., The cotton trade and industrial Lancashire 1600-1780 (Manchester, 1931).

Wall, R., 'The composition of households in a population of 6 men to 10 women: south-east Bruges in 1814', in R. Wall, J. Robin and P. Laslett, eds., Family forms in historic Europe, (Cambridge, 1983), pp. 421-74.

Wiesner, M. E., 'Guilds, male bonding and women's work in early modern Germany', Gender \& History, 1 (1989), pp. 125-37. 